\title{
Contraceptive potential of antibodies to the zona pellucida*
}

\author{
C. J. Henderson $\dagger$, M. J. Hulme and R. J. Aitken \\ MRC Reproductive Biology Unit, Centre for Reproductive Biology, 37 Chalmers Street, \\ Edinburgh EH3 9EW, U.K.
}

\begin{abstract}
Summary. The notion of a contraceptive vaccine based on gamete-specific surface antigens was first proposed over a decade ago, as the result of in-vitro and in-vivo studies, and in recent years has been the subject of intensive research. In particular, the zona pellucida has attracted much attention as a potential target for immunological intervention in the fertilization process. Such is the rapidly-expanding nature of research into the biochemical and biological characterization of this structure, that a review of the implications for the development of a contraceptive vaccine seems timely.
\end{abstract}

Keywords: zona pellucida; contraceptive vaccine; antibodies

\section{Introduction}

The global human population continues to grow at an ever-increasing rate, currently by $>220000$ per day. By the end of the century, the world population is forecast to reach $6.3 \times 10^{9}$, double the figure of 1960 , and about $80 \%$ of the people will live in Third World countries (Population Statistics Division, OPCS, 1987). It has been widely recognized for some time that new methods of birth control are necessary to halt, and ultimately reverse, this inexorable trend in population growth.

Amongst the various methods of birth control that have been proposed over the past decade or two, arguably the one that has stimulated the greatest interest is that of a contraceptive vaccine (Shivers, 1974). The potential offered by the immunological approach, affording prolonged yet reversible protection against pregnancy, has always made the development of a vaccine highly desirable. In addition to being simple and cheap to make, the use of existing health service infrastructures of Third World nations to administer a vaccine would be an advantage.

An ideal point for the immunological disruption of fertility is the act of fertilization itself. At ejaculation, about $220 \times 10^{6}$ spermatozoa are deposited in the human female reproductive tract, in order to interact with just one other cell-the ovum. The cell recognition events which constitute the fertilization process are, therefore, extremely specific and, for this reason, exhibit some potential as a point of attack for a contraceptive vaccine. There are two such recognition events involved in spermovum interaction, involving the zona pellucida and vitelline membrane of the oocyte respectively, both of which have been shown to be susceptible to immunological interference (Gwatkin et al., 1977; Dor et al., 1981). The zona péllucida, in particular, exhibits promise as the target for a contraceptive vaccine because it possesses tissue (Sacco \& Shivers, 1973; Palm et al., 1979) and species-specific (Hanada \& Chang, 1972; Hartmann et al., 1972) immunogenic domains which are involved in spermovum interaction. The experiments conducted by Gwatkin \& Williams (1976), demonstrating that

\footnotetext{
*Presented as the Arthur Walpole Memorial Lecture to the Society for the Study of Fertility at the University of York, 1987.

†Present address: ICRF Molecular Pharmacology and Drug Metabolism Laboratory, Hugh Robson Building, George Square, Edinburgh EH8 9XD, U.K.
} 
exposure of capacitated spermatozoa to solubilized homologous zonae pellucidae blocks the ability of the former to interact subsequently with the intact ovum, led to the concept of a zona receptor for spermatozoa, which becomes modified during the post-fertilization block to polyspermy (Oikawa et al., 1975a; Florman \& Wassarman, 1985). Subsequent studies have shown the sperm receptor to be extremely sensitive (particularly in the hamster) to protease attack (Hartmann \& Gwatkin, 1971), and susceptible to occlusion by lectins (Barros \& Yanagimachi, 1972; Oikawa et al., 1975b), polyvalent antibodies (Aitken \& Richardson, 1981b) or even univalent (Fab) anti-zona antibody fragments (Sacco et al., 1984). The most detailed characterization of the zona sperm receptor so far has been achieved for the mouse (Florman \& Wassarman, 1985) in which this activity has been shown to reside in the oligosaccharide side-chains of a zona glycoprotein of $M_{\mathrm{r}} 83000$. The specificity of sperm--zona interaction and the apparent susceptibility of this event to immunological attack have generated considerable interest in the development of anti-zona antibodies as contraceptive agents. The fact that such antibodies would achieve their effect on fertility by blocking conception (rather than the abortifacient mechanism of action associated with alternative approaches to vaccine development, when, for example, hCG is used as the target) also enhances the acceptability of a zona-orientated vaccine programme.

\section{In-vitro studies}

The concept of using the zona pellucida as the target for a contraceptive vaccine originated from research, carried out just over a decade ago, on the influence of anti-ovarian antisera on mammalian in vitro fertilization systems (Shivers et al., 1972; Jivek \& Pavlok, 1975; Tsunoda \& Chang, 1976a, b, 1977). In these studies, it was observed that antisera raised against aqueous extracts of ovarian tissue were able to block fertilization by inhibiting the attachment and binding of spermatozoa to the zona pellucida. It was rapidly established that the ovarian antigens responsible for this inhibitory activity originated from the zona pellucida and that antibodies raised against mechanically isolated zonae per se were fully competent to block in-vitro fertilization in laboratory rodents (Tsunoda, 1977; Tsunoda \& Chang, 1978).

A major component of the mechanism of action of anti-zona antibodies involves the inhibition of sperm attachment to the zona pellucida by occlusion of sperm binding sites on the zona surface (Aitken et al., 1981). The occlusion of these binding sites is generally thought to involve a process of steric hindrance, rather than direct interaction with the sperm receptor itself. This is particularly true of polyclonal antibodies which, because of their cross-linking activity, are able to induce the formation of an immunoprecipitate (Fig. 1) on the outer zona surface which masks the binding sites for spermatozoa (Aitken \& Richardson, 1981b). If the cross-linking activity of anti-zona antisera is destroyed through the preparation of Fab fragments then, in most cases, their abilities to induce the formation of an immunoprecipitate and to block sperm-zona interaction are abolished (Ahuja \& Tzartos, 1981; Aitken et al., 1982).

The deposition of an immunoprecipitate on the zona surface is not an absolute requirement for the disruption of sperm-zona interaction, however, since monoclonal anti-zona antibodies (which because of their specificity have a limited capacity for cross-linkage and precipitate formation) are also effective inhibitors of fertilization (Isojima et al., 1984; Koyama et al., 1985; East et al., 1985). This is particularly true when the monoclonal antibodies have been raised against zona antigens from the same species as that used for the in-vitro fertilization assay (Isojima et al., 1984; Koyama et al., 1985; East et al., 1984, 1985). In such circumstances, the monoclonal antibodies are thought to bind to high density antigenic sites on the zona surface which are sufficiently close to the sperm binding site to hinder the latter sterically. Alternatively, even the limited degree of cross-linking achieved with monoclonal antibodies may be sufficient to stabilize the zona pellucida, rendering this structure less susceptible to sperm penetration, even though sperm binding to the zona surface may occur (East et al., 1985). 


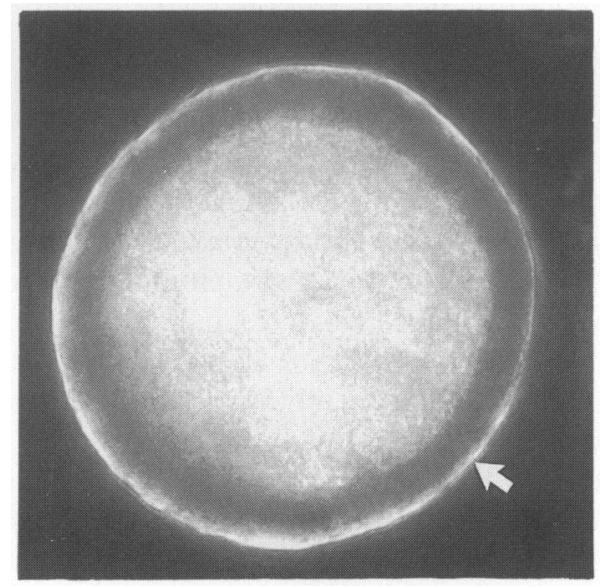

Fig. 1. Immunoprecipitate formation on the outer surface of the zona pellucida after exposure to anti-zona antibodies. Mouse ova were incubated with polyclonal antibodies raised, in rabbits, against mechanically isolated mouse zonae pellucidae. The presence of an immunoprecipitate on the outer zona surface is indicated by the white arrow.

In contrast, monoclonal antibodies are generally ineffective in disrupting sperm-zona interaction, when the gametes used in the in-vitro fertilization assay are from a heterologous species, even though immunological cross-reactivity may be demonstrable (Isojima et al., 1984; Koyama et al., 1985). In such circumstances, the antigenic site density must be too low for the antibodies to occlude the sperm binding sites or to prevent sperm penetration. However, restoration of the steric hindrance mechanism by adding a second, polyclonal, antiserum directed against mouse immunoglobulin will, in the presence of such monoclonals, lead to immunoprecipitate formation and the disruption of sperm binding in heterologous systems (Koyama et al., 1985). A notable exception is a report of two monoclonal antibodies directed against the pig zona pellucida which were capable of blocking human sperm-zona interaction without the need for a second, cross-linking antibody. One of these monoclonals formed a precipitin line on immunoelectrophoresis with pig zona material and must have been directed against an epitope present as multiple copies on a single antigen molecule, inhibiting sperm-zona interaction by the steric hindrance mechanism described above (Mori et al., 1985). The second monoclonal antibody described in this study did not form a precipitin line during immunoelectrophoresis and suggests the presence of a cross-reactive epitope on the human zona pellucida which is adjacent to, and able to occlude, the sperm binding site (Mori et al., 1985).

Although antisera have been prepared which do appear to interact directly with the sperm receptor (Sacco et al., 1984), the fact that anti-zona antibodies can inhibit sperm-zona interaction by steric hindrance (Aitken \& Richardson, 1981b) is absolutely central to any strategy for engineering a contraceptive vaccine. This is because sperm-zona interaction in the human is a highly speciesspecific event (Bedford, 1977) which is probably mediated by the carbohydrate side-chains on the zona glycoproteins (Florman \& Wassarman, 1985). Since it is not currently possible to engineer a vaccine containing defined carbohydrate sequences, it is crucial that antibodies directed against zona peptides per se exhibit the ability to interfere with adjacent oligosaccharide sperm-binding sites. The fact that antibodies directed against the polypeptide backbone of zona glycoproteins can still disrupt sperm-zona interaction by interfering with the binding process (Henderson et al., 1987a) or sperm penetration (East et al., 1985) supports the view that antibodies raised against antigens generated by recombinant DNA techniques or direct peptide synthesis should exhibit contraceptive activity in vivo and in vitro. 


\section{In-vivo studies}

\section{Passive immunization studies}

Passive immunization studies in a variety of species quickly followed the early in-vitro work. It was rapidly established in hamsters (Oikawa \& Yanagimachi, 1975), mice (Jilek \& Pavlok, 1975) and rats (Tsunoda \& Chang, 1976a, b) that passive immunization with antisera against ovarian antigens could induce infertility. Antibodies against cumulus-free mouse eggs or mechanically isolated mouse zonae also proved effective (Tsunoda \& Chang, 1978; Sacco, 1979); indeed, prolonged periods of infertility were observed following a single administration of anti-zona antibodies (Tsunoda \& Sugie, 1977; Sacco, 1979). Investigation of this last observation revealed that anti-zona antibodies possessed the ability to bind not only to ovulated oocytes, but also to those still in their follicles, with the result that the animal remained infertile for several successive cycles until all ova coated with anti-zona antibodies had been ovulated. Such ova recovered from passively immunized animals were found to possess an immunoprecipitate on the outer surface of the zona pellucida, providing evidence that the mechanism of action of such antibodies in vivo was the same as in vitro, by sterically hindering the binding of spermatozoa to their receptors on the zona pellucida. Although some workers (Dudkiewicz et al., 1975; Tsunoda \& Chang, 1978) have suggested, in the hamster and mouse respectively, that anti-zona antibodies may have effects after fertilization, others have shown an absence of interference with zona shedding and implantation (Tsunoda \& Whittingham, 1982) using purified anti-zona antibodies.

The development of monoclonal antibodies against specific zona determinants has further refined this passive immunization approach (East et al., 1984, 1985). Hence, monoclonal antibodies directed against ZP2 (a major component of the mouse zona pellucida which does not include the sperm binding site) have been shown to be extremely effective in preventing the fertilization of mouse ova in passive immunization studies (East et al., 1984). Significantly, this inhibition of fertilization was reversible and did not involve any disruption of folliculogenesis or ovulation. Subsequent studies with monoclonal antibodies directed against ZP3, a sulphated glycoprotein component of the mouse zona pellucida with sperm binding activity, also succeeded in demonstrating a contraceptive effect mediated through the specific disruption of fertilization without any effect on ovarian function (East et al., 1985). These studies confirm the contraceptive potential of anti-zona antibodies in vivo. Moreover, they indicate that such efficacy need not involve a direct interaction between the antibody and the sperm receptor site. None of the antibodies utilized by East et al. $(1984,1985)$ were directed against the binding site, and, because of their monoclonal origins, they did not possess sufficient crosslinking activity to occlude these sites by steric hindrance. Simply by binding to the zona pellucida in quantities sufficient to stabilize this structure and prevent sperm penetration to the perivitelline space, such antibodies were extremely effective contraceptive agents.

\section{Active immunization studies}

The first example of active immunization employing heterologous zona antigens was provided by Gwatkin et al. (1977), who immunized mice with heat-solubilized hamster zonae pellucidae and induced a reversible state of infertility, with no side-effects. However, the ova recovered from these immunized animals possessed 'perforated' zonae pellucidae, the antibodies seriously affecting the integrity of the zonae. Based on the previously demonstrated cross-reactivity between rat and mouse zonae pellucidae (Aitken \& Richardson, 1980), and the observation that antibodies against isolated mouse zonae will inhibit fertilization of both mouse and rat eggs in vitro (Tsunoda \& Chang, 1978; Tsunoda et al., 1981), we carried out a series of experiments in which the duration of infertility after active immunization with heterologous antigen was correlated with the amount of antigen administered (Fig. 2a). The greater the amount of antigen used, the longer the period of 
(a)

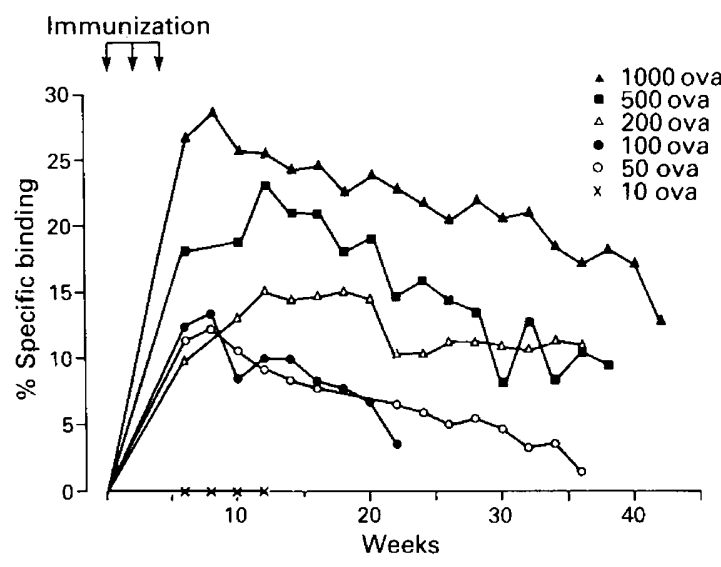

(b)

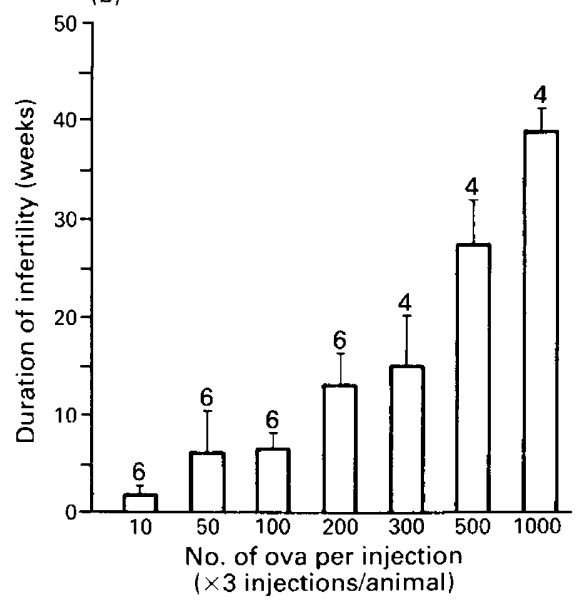

Fig. 2. Anti-zona antibody titre (a) and duration of infertility (b) in the rat after active immunization against mouse zonae pellucidae. Rats were actively immunized against successively larger numbers of mouse zonae pellucidae antigens using Freund's adjuvant. Antibody titre and the duration of infertility were monitored.

infertility induced, until the animals were rendered infertile for what was effectively their reproductive lifespan. Figure 2(b) illustrates the relationship between antigen dose and antibody titre in this model. The infertility induced in such actively immunized rats was invariably dissociated from any adverse side-effects regardless of whether the source of antigen used was an aqueous extract of ovarian tissue (Aitken \& Richardson, 1981a), cumulus-free oocytes (Aitken \& Richardson, 1981c) or mechanically isolated zonae (D. W. Richardson, unpublished observations). Of particular importance is the fact that the induction of active immunity against the zona pellucida did not influence the normality of ovarian function as indicated by direct measurement of plasma progesterone concentrations or vaginal cytology (D. W. Richardson, unpublished observations). Typically, such immunized animals mated normally and exhibited a series of pseudopregnancies until the antibody titres declined to a point where conception could not be prevented (Fig. 3). Immunized animals not housed with males exhibited an unbroken sequence of normal oestrous cycles (D. W. Richardson, unpublished observations). As further evidence of normal ovarian function immunized animals autopsied on Days 1, 2, 3,5 or 9 after mating possessed normal numbers of corpora lutea (D. W. Richardson, unpublished observations; Table 1).

Despite the above findings indicating that active immunization results in the inhibition of fertilization without disrupting the processes of follicular growth and ovulation, interference with the latter has been observed when rabbits were immunized with pig zona antigens. In this model, the induction of infertility was associated with the inhibition of normal follicular development and ovulation (Gwatkin et al., 1980; Wood et al., 1981; Skinner et al., 1984), ultimately resulting in the cessation of follicular growth and a reduction in the number of primordial follicles present in the ovary. These data have been interpreted as indicating the destruction of the developing oocyte pool by circulating anti-zona antibodies, when zona antigens are first expressed on the surface of the vitelline membrane (Skinner et al., 1984).

Although this model is of considerable interest in elucidating the role of the oocyte in controlling follicular cell differentiation and possibly the aetiology of certain ovarian diseases, its relevance to the development of a contraceptive vaccine is questionable. The biology of fertilization in the rabbit differs from that observed in other animal models, and the human, in that the zona pellucida only plays a limited role in restricting the passage of spermatozoa into the perivitelline space. As a result, it is normal to find many accessory spermatozoa in the perivitelline space of rabbit ova after 


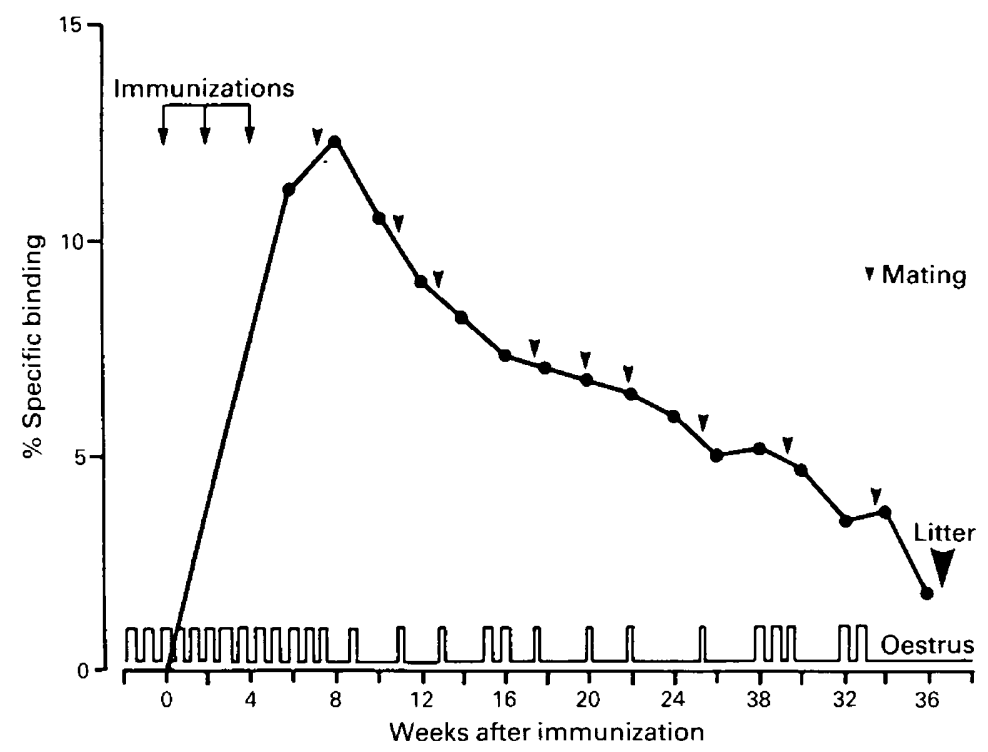

Fig. 3. Induction of infertility in the rat after active immunization against mouse zonae pellucidae. A single experimental profile is shown from one of a group of rats actively immunized against mouse zonae pellucidae using Freund's adjuvant. Antibody titre was monitored by radioimmunoassay and oestrus and mating were detected by vaginal smears.

Table 1. Comparison between corpora lutea numbers in the ovaries of actively immunized and control rats

\begin{tabular}{|c|c|c|c|}
\hline Days p.c. & Treatment & $\begin{array}{l}\text { No. of } \\
\text { rats }\end{array}$ & $\begin{array}{l}\text { Mean no. } \\
\text { ( } \pm \text { s.e.m.) of } \\
\text { CL per ovary }\end{array}$ \\
\hline Day 1 & $\begin{array}{c}\text { Immunized } \\
\text { Controls }\end{array}$ & $\begin{array}{l}10 \\
10\end{array}$ & $\begin{array}{l}15.3 \pm 1.21 \\
14.1 \pm 0.83\end{array}$ \\
\hline Day 2 & $\begin{array}{l}\text { Immunized } \\
\text { Controls }\end{array}$ & $\begin{array}{l}10 \\
10\end{array}$ & $\begin{array}{l}13.8 \pm 0.96 \\
14.3 \pm 0.66\end{array}$ \\
\hline Day 3 & $\underset{\text { Controls }}{\text { Immunized }}$ & $\begin{array}{l}10 \\
10\end{array}$ & $\begin{array}{l}13.9 \pm 0.58^{*} \\
10.9 \pm 1.12\end{array}$ \\
\hline Day 5 & $\begin{array}{l}\text { Immunized } \\
\text { Controls }\end{array}$ & $\begin{array}{l}10 \\
10\end{array}$ & $\begin{array}{l}13.8 \pm 0.73 \\
13.4 \pm 0.15\end{array}$ \\
\hline Day 9 & $\begin{array}{c}\text { Immunized } \\
\text { Controls }\end{array}$ & $\begin{array}{l}15 \\
15\end{array}$ & $\begin{array}{l}14.4 \pm 0.52 \\
14.9 \pm 0.68\end{array}$ \\
\hline
\end{tabular}

${ }^{*} P<0.05$ compared with control value $(t$ test).

fertilization in vivo. A difference in the physiology of the rabbit zona pellucida is also indicated by the fact that this structure can be extensively cross-linked with lectins to the point at which it cannot be solubilized by proteases and yet spermatozoa can still penetrate through the zona and gain access to the oocyte (Bedford \& Cross, 1978). In other eutherian mammals, such cross-linking of the zona pellucida with lectins leads to the inhibition of fertilization through disruption of the sperm-zona interaction (Oikawa et al., 1975b). Most importantly in the present context, exposure of the rabbit ovum to anti-pig zona antibodies in vitro does not disrupt the sperm binding process, despite the presence of an immunoprecipitate on the zona surface (Sacco et al., 1981). Such 
observations indicate that the physiology of the rabbit zona pellucida is quite different from that observed in most other eutherian mammals and that the mechanisms by which anti-zona antibodies achieve their contraceptive effect are not operational in this species.

One can only speculate as to why the rabbit oocyte should be so susceptible to the cytotoxic effect of anti-zona antibodies, when no such disruption of oocyte viability, and thence folliculogenesis, has been observed in rodent models in active or passive immunization studies. It may be a question of antibody titre. In rabbit studies in which a disruption of ovarian function has been induced large doses of antigen (300-315 $\mu \mathrm{g}$ zona glycoproteins) together with Freund's adjuvant have been used in a model which is notoriously sensitive to the elicitation of humoral immune responses (Wood et al., 1981; Skinner et al., 1984). In contrast, as little as $450 \mathrm{ng}$ mouse zona glycoprotein will induce infertility in an actively immunized rat (Aitken et al., 1984) without any influence on ovarian activity. The active immunization of rabbits with lower amounts of more highly purified pig zona antigens has led to the induction of infertility in rabbits with no adverse side-effects (Skinner \& Dunbar, 1984).

Other species used in active immunization studies include the dog (Mahi-Brown et al., 1982, 1985), in which the effects of varying the dose and purity of pig zona antigen, as well as the adjuvant, on hormone profiles and ovarian function were monitored. Again, the major conclusion from this study was that the amount and purity of antigen used in active immunization was crucial to circumvent potential problems with ovarian dysfunction. Adjuvants with the same efficacy as Freund's adjuvant, but with milder physiological side-effects, were also reported.

The cross-reactivity exhibited between primate and pig zonae pellucidae (Sacco et al., 1981, $1983 \mathrm{~b}$ ) led to the use of the latter in a series of active immunization studies with various primate species, and we have studied the common marmoset, Callithrix jacchus jacchus. Owing to the wellknown intolerance of New World monkeys to Freund's adjuvant, and previous experimental evidence indicating a loss of reproductive function when using Freund's adjuvant in this particular species, alum (aluminium trihydroxide) was used in the active immunization schedules involving these animals. This compound is a much milder adjuvant, necessitating more frequent boosting of the animals in order to maintain antibody levels and infertility. A typical experimental profile from the marmoset study is shown in Fig. 4. In the control group, immunized only with alum, the females became pregnant within 2 weeks of the introduction of a male, whereas those animals actively immunized against the pig zona pellucida $(60 \mu \mathrm{g})$ remained infertile for a mean period of $47( \pm 15)$ weeks $(\mathrm{N}=3)$, with one animal rendered infertile for 75 weeks. Monitoring of plasma progesterone concentrations by radioimmunoassay indicated little disruption to ovarian cyclicity. The experimental animals finally became pregnant when a mating event coincided with a trough of antibody titre, or with an overall lowering of the antibody titre.

Other primate species used in active immunization studies include cynomolgus monkeys (Macaca fascicularis), in which Gulyas et al. (1983) reported the induction of reversible infertility associated with menstrual irregularities and oocyte atresia, following immunization with pig zonae pellucidae ( $360 \mu \mathrm{g}$ in alum). However, the authors stated that, since the zona preparation used in this study was contaminated with non-zona material, they were unable to conclude that such sideeffects were due to immunological attack on the zona itself, or whether antibodies against other ovarian components were responsible.

Sacco et al. (1983b, 1986a, 1987) have used squirrel monkeys (Saimiri sciureus). The immunogen used in these experiments was a purified component of $M_{\mathrm{r}} 55000$ of the pig zona pellucida, and a large number of animals (50) was used. After active immunization, high antibody titres were induced in the monkeys for periods up to 18 months, with resultant induction of infertility. Initial disturbances in hormonal status were observed in these animals, along with histological changes suggesting interference in folliculogenesis, although by 10-15 months after immunization hormonal and laparoscopic data indicated a recovery of ovarian function despite continuing high titres of anti-zona antibodies (Sacco et al., 1987). Although the antigen used in this particular experiment was purified, it was administered in relatively high amounts $(200 \mu \mathrm{g})$, and, in addition, the study used Freund's adjuvant; 


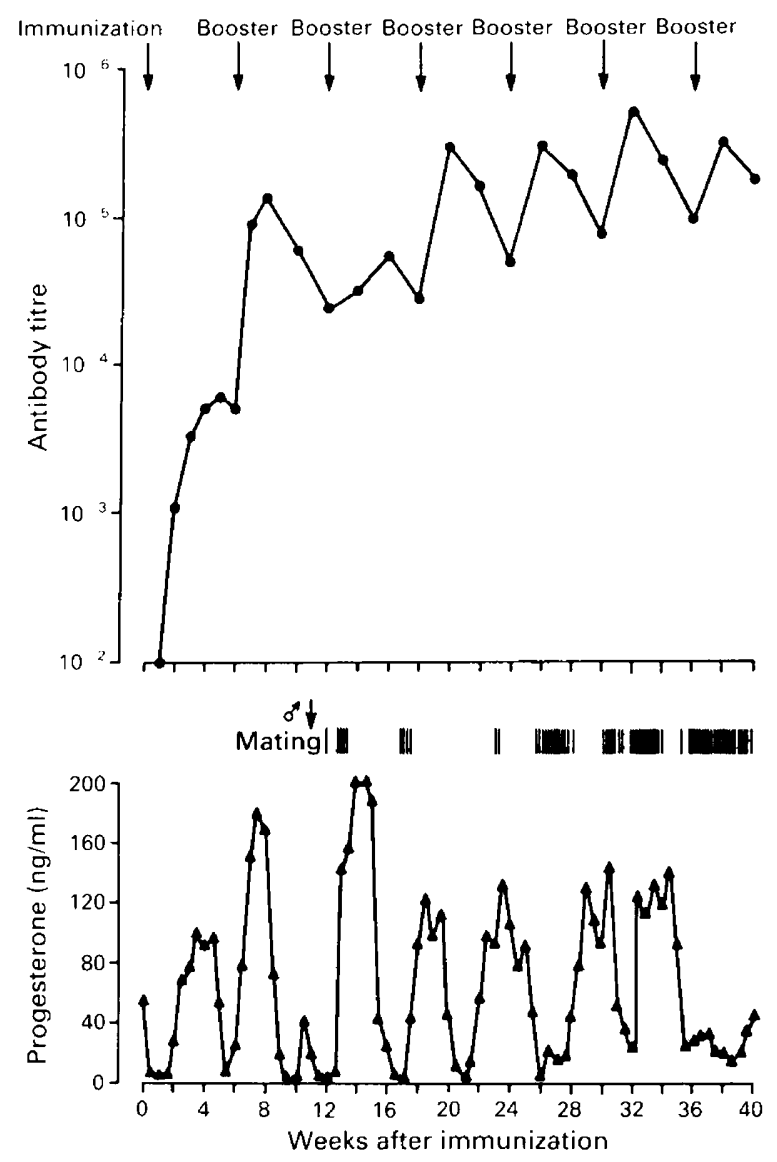

Fig. 4. Induction of infertility in the marmoset after active immunization against pig zonae pellucidae. A single experimental profile is shown from one of a group of marmosets immunized against pig zonae pellucidae, using alum as adjuvant. Antibody titre was monitored by radioimmunoassay (Hulme et al., 1982). Details of the management of the marmosets and the methods used to monitor their ovarian cyclicity are given by Hearn et al. (1975).

the authors acknowledge that the deleterious effects observed on ovarian structure and function may have been entirely due to the latter.

Bonnet monkeys were used by Bamezai et al. (1986), and were actively immunized with $200 \mu \mathrm{g}$ of intact pig zonae pellucidae with Freund's adjuvant. Again, hormonal changes were observed, with both progesterone and oestradiol concentrations falling during high anti-zona antibody titres, although normal cyclicity was recovered when antibody titres declined. Bamezai et al. (1986) stated that moderate immunization against the pig zona pellucida did not irreversibly impair ovarian function and fertility, although they did not appear to consider the possibility of contamination of their zona preparation, or the possible effects of using Freund's adjuvant.

Although more work is necessary in the area of active immunization against the pig zona pellucida, particularly with primate species in properly controlled trials, the studies reported so far encourage continued research into this structure as the basis of a contraceptive vaccine. The overall lesson from these studies is that active immunization schedules should use purified antigen at levels low enough to prevent any side-effects, whilst inducing and maintaining infertility. The results to date support the view that this is an achievable objective. 


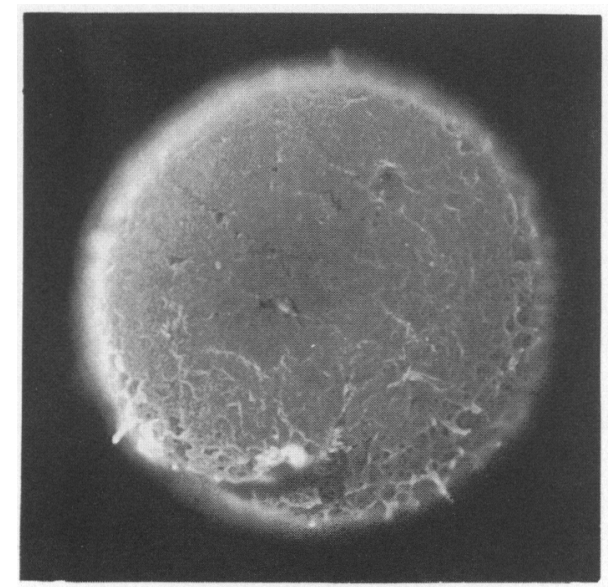

Fig. 5. Cross-reactivity of human and pig zonae pellucidae demonstrated by indirect immunofluorescence. Salt-stored human ova were incubated for $1 \mathrm{~h}$ at $37^{\circ} \mathrm{C}$ in a polyclonal antiserum raised against intact pig zonae pellucidae, and then further incubated at $37^{\circ} \mathrm{C}$ for $30 \mathrm{~min}$ in a second, fluorescein-labelled antibody raised against rabbit IgG. Immunofluorescence was observed using a fluorescence microscope.

The use of heterologous zona antigens in these, and other, studies is of crucial importance; if homologous antigens were necessary, then the development of a contraceptive vaccine for human use would be seriously hampered by the constraints, both physical and ethical, placed upon the collection of sufficient human zonae pellucidae for experimental purposes. Fortunately, Sacco (1977) has demonstrated that human and pig zonae pellucidae share common antigens, and exhibit cross-reactivity. This is illustrated in Fig. 5, using indirect immunofluorescence with a human ovum and an antiserum raised against components of the pig zona pellucida. The binding of the antibodies to the outer zona surface can be clearly seen and this interaction has been shown to inhibit the subsequent binding of human spermatozoa to the human zona pellucida (Trounson et al., 1980; Hasegawa et al., 1985).

Thus, by the beginning of the decade, attention was turning to the biological and, more particularly, the biochemical characterization of antigens from the pig zona pellucida, in order to produce a basis for the development of a contraceptive vaccine.

\section{The pig zona pellucida}

Several methods have been developed for the large-scale isolation of pig zonae pellucidae, most of them using techniques for breaking up the structure of the ovary into successively smaller pieces and releasing the ova and zonae pellucidae from the follicles (Dunbar \& Raynor, 1980; Dunbar et al., 1980; Noda et al., 1981; Sacco et al., 1981, 1983a; Hedrick \& Wardrip, 1986). We use a commercial meat grinder, passing the ovaries through several times, with different sized cutting screens; details of the protocol are as follows:

(1) Ovaries removed at slaughter and stored deep frozen

(2) Ovaries thawed and trimmed of extraneous tissue immediately before processing

(3) Ovaries successively broken up in meat grinder, copious irrigation with ice-cold saline $(0.9 \%$ $w / v)$ between passes

(4) Homogenate passed through 500 and $210 \mu \mathrm{m}$ nylon meshes to remove large debris

(5) Filtrate passed through $75 \mu \mathrm{m}$ nylon mesh to trap eggs and washed off with ice-cold saline

(6) Centrifuged to concentrate and crude preparation applied to discontinuous Percoll gradient 
(7) Eggs aspirated from top of Percoll gradient, and washed free of Percoll

(8) Eggs gently homogenized to free zonae, and washed to remove cell contents

(9) Zonae heat-solubilized $\left(20 \mathrm{~min}, 76^{\circ} \mathrm{C}\right)$

(10) Zonae ultracentrifuged, protein content estimated, and zona material lyophilized.

Steps 6 and 7 in this protocol are unique in the area of zonae preparation, and produce an extremely pure preparation, by completely removing potential contaminants. Heat-solubilization of the zonae at the crude oocyte stage results in contamination; by separating the oocytes and zonae by density gradient centrifugation, then using the shearing forces generated in a Potter homogenizer to release the oocytes and another centrifugation step to wash the zonae, we can produce a heat-solubilized preparation consisting only of zona pellucida glycoproteins. In 3 years, we have processed some 25000 pig ovaries, yielding over $225 \mathrm{mg}$ zona glycoprotein.

Two-dimensional sodium dodecyl sulphate/polyacrylamide gel electrophoresis (SDS/PAGE) of the pig zona pellucida reveals the presence of 4 glycoprotein families or 'charge-trains', named ZP1-4 in order of decreasing average molecular mass (Fig. 6a). These glycoproteins and their isomers span the molecular mass range from approximately 20000 to 125000 , and have isoelectric points covering the pH scale from 4 to 8.5 (Dunbar \& Raynor, 1980; Dunbar et al., 1981; Sacco et al., 1981, 1983b; Yurewicz et al., 1983; Noda et al., 1983; Hedrick \& Wardrip, 1986). The microheterogeneity exhibited by these molecules, residing in the carbohydrate moiety (Hedrick \& Wardrip, 1981; Hedrick et al., 1985), is typical of glycoproteins, but is possibly the most extreme example yet known. Although the carbohydrate moieties of the zona glycoproteins are doubtless crucial for the sperm receptor to function (Florman \& Wassarman 1985), the current inability to synthesize artificially defined carbohydrate sequences upon which a contraceptive vaccine might be based suggests that further investigation of the polypeptide backbones of the zona glycoproteins is warranted. The major consequence of the charge and molecular mass isomerization exhibited by the zona glycoproteins is the difficulty in isolating any single isomer in sufficient quantity for detailed biochemical analysis. To overcome this obstacle, chemical deglycosylation of the pig zonae glycoproteins has been carried out (Hedrick et al., 1985; Sacco et al., 1986b; Henderson et al., 1987a).

\section{Deglycosylation of pig zonae pellucidae glycoproteins}

The methodology used to remove chemically the carbohydrate side-chains from pig zonae glycoproteins involves the use of trifluoromethanesulphonic acid (TFMS) in conjunction with anisole (Karp et al., 1982). We have previously published details of our protocol and subsequent gas chromatographic analysis to demonstrate the complete removal of carbohydrate (Henderson et al., 1987a). The effect of deglycosylation on the electrophoretic profile of the zonae glycoproteins is quite dramatic. After separation on one-dimensional SDS/PAGE, 5 discrete polypeptides can be resolved from the deglycosylated fraction (DGZP), with approximate molecular masses of 66000 (from ZP1), 52000 (from ZP2), 36000,32000 (both from ZP3) and 16000 (from ZP4). These polypeptides are so basic after the removal of carbohydrate that they barely enter the first dimension isoelectric focussing gel when run on two-dimensional SDS/PAGE under the same conditions as the intact zona fraction (ZP). As a result, the polypeptides run as a column of spots in the second dimension (Fig. 6b). Although the component of $M_{\mathrm{r}} 32000$ (DG-32) appears to possess residual charge isomerization, this is almost certainly due to molecular changes, such as carbamylation, sulphation or phosphorylation, of the amino acid residues in the polypeptide backbone itself.

Hedrick et al. (1985) have also used TFMS treatment to remove carbohydrate, generating polypeptides of approximate molecular masses $71000,56000,40000$ and 37000 . Taking into account the limits of accuracy expected when calculating molecular masses from electrophoretic mobility, these figures are very similar to those found by our own group. Hedrick et al. (1985) also reported that although $>95 \%$ of the carbohydrate had been removed, the microheterogeneity was not completely eliminated due to the protein itself being slightly microheterogeneous. Residual heterogeneity following treatment of the pig zona glycoproteins with TFMS has also been reported by Timmons 


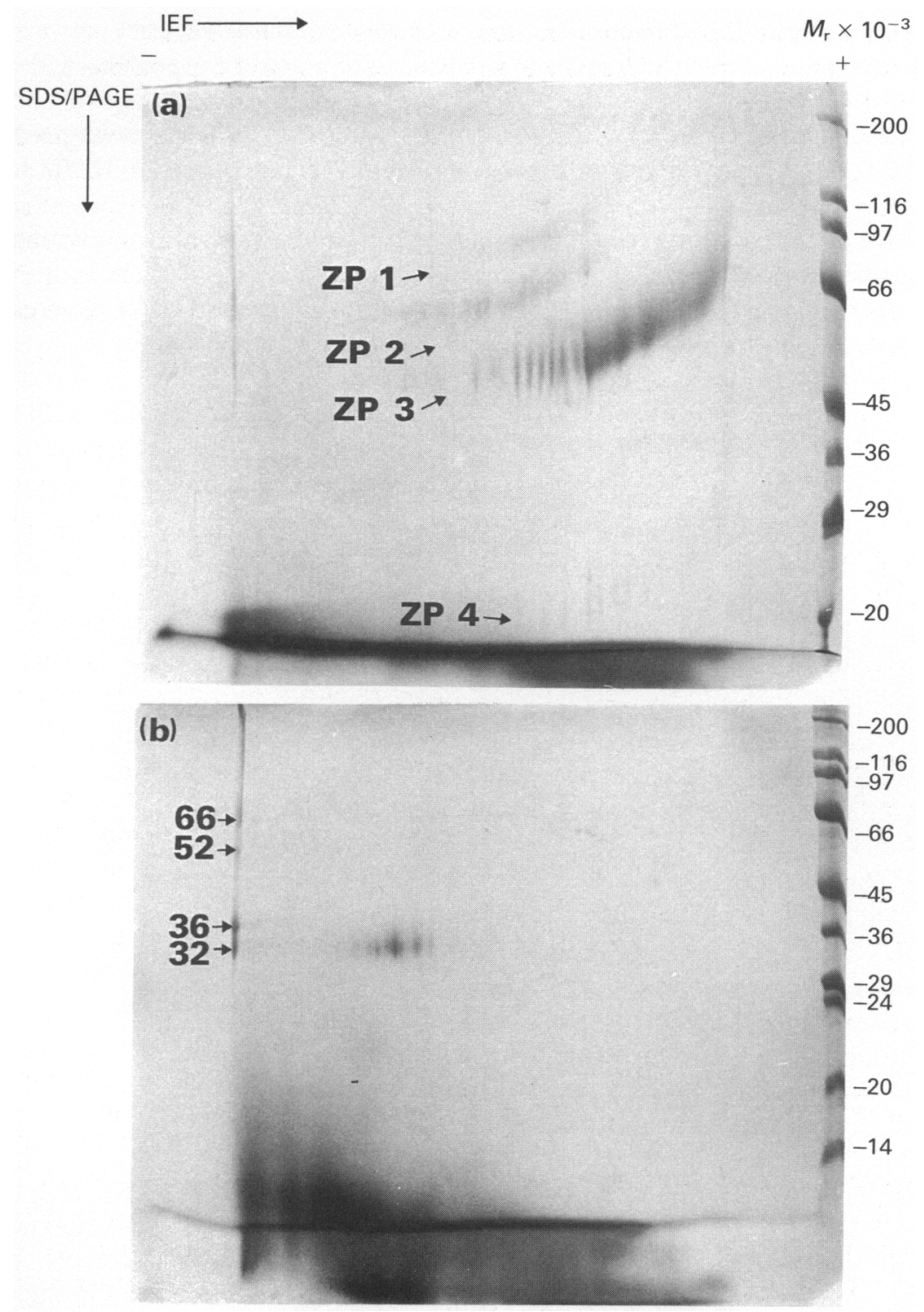

Fig. 6. Two-dimensional electrophoretic profiles of (a) intact pig zonae pellucidae (ZP) and (b) deglycosylated pig zonae pellucidae (DGZP). Two-dimensional sodium dodecylsulphate/ polyacrylamide gel electrophoresis was carried out according to the method of O'Farrell (1975). Samples of ZP and DGZP (Henderson et al., 1987a, b) were prepared for electrophoresis by dissolution in reduced sample buffer, and run in the first dimension in rod gels over the $\mathrm{pH}$ range 4-9, and in the second dimension in $10 \%$ acrylamide gels over the molecular mass range 10000-200 000. Polypeptides were visualized by staining with Coomassie blue-R. Residual ampholine staining can be seen at the bottom of each gel. (From Henderson et al., 1987b.)

et al. (1987); although unable to detect carbohydrate by conventional means, these workers showed by lectin blotting that trace amounts of carbohydrate remained on the deglycosylated polypeptides.

TFMS has also been used by Sacco et al. (1986b), working with purified ZP3 to generate DGZP3, and they have reported that enzymic removal of the carbohydrate side-chains from pig zona 
glycoproteins by using endo- $\beta$-galactosidase to remove lactosaminoglycans (Yurewicz et al., 1987). After enzymic digestion, ZP3 yielded a pair of partly deglycosylated glycoproteins with approximate masses of 46000 and 42000 , termed the $\alpha$ - and $\beta$-glycoproteins respectively. Several lines of evidence now exist which demonstrate that the ZP3 family from the pig zona pellucida is composed of two subfamilies, $\alpha$ and $\beta$, based upon polypeptide backbones of molecular masses 32-37000 and 36-40 000 respectively.

The removal of carbohydrate from the pig zona glycoproteins posed two questions. First, had the immunogenicity of the molecules been affected? In the absence of carbohydrate, would the polypeptide backbones remain immunogenic? Secondly, if antibodies could be produced to the DGZP fraction, would they possess any biological (i.e. contraceptive) activity?

\section{Antibodies to the deglycosylated zona polypeptides}

Polyclonal antibodies have been raised to the ZP and DGZP fractions in rabbits (Henderson et al., 1987a), and the question of immunogenicity was answered by using the antiserum to DGZP to probe a two-dimensional immunoblot of intact ZP glycoproteins; the antibodies recognized predominantly the ZP3 family, cross-reacting with all isomers within the charge-train, thus demonstrating that the polypeptide backbones of the ZP glycoproteins retained the ability to induce the formation of antibodies. Sacco et al. (1986b) reported that deglycosylated ZP3, whilst retaining significant immunogenic potential, exhibited altered antigenicity after the removal of carbohydrate. These authors were also able to raise polyclonal antisera against the pair of partly deglycosylated glycoproteins of molecular masses 46000 and 42000 , that were generated by enzymic means from the parental ZP3 family. Furthermore, Wardrip et al. (1986) reported the production of monoclonal antibodies against the two fully deglycosylated polypeptides of $M_{\mathrm{r}} 37000$ and 40000 , again emphasizing that the polypeptide backbones of the pig zona pellucida glycoproteins were immunogenic in their own right.

To test the contraceptive efficacy of these antisera, and others, we have used an in-vitro human gamete bioassay (Henderson et al., 1987a, b). For this purpose, unfertilized human ova were obtained from in-vitro fertilization programmes and stored in a high-salt medium containing $1.5 \mathrm{M}-$ magnesium chloride and $0 \cdot 1 \%$ dextran (Yanagimachi et al., 1979). This medium has the effect of destroying the oocyte, whilst retaining the structure and function of the zona pellucida. The zonae were removed from this solution and washed in Medium BWW (Biggers et al., 1971), before being preincubated in the antisera under test for $2-3 \mathrm{~h}$ at $37^{\circ} \mathrm{C}$. The zonae were washed again, and added to $100 \mu \mathrm{l}$ droplets under paraffin oil, containing fully capacitated human spermatozoa at a concentration of $10 \times 10^{6} \mathrm{ml}$. After incubation for $16 \mathrm{~h}$ at $37^{\circ} \mathrm{C}$, the zonae were washed to remove any loosely bound or non-adherent spermatozoa, and then observed microscopically. Relative to a control antiserum (non-immune rabbit serum), antibodies to both the ZP and DGZP fractions completely abolished sperm binding to the zona pellucida (Henderson et al., 1987a), thus demonstrating that the polypeptides of the DGZP fraction possessed antigenic epitopes with contraceptive potential (Fig. 7; Table 2).

\section{Isolation and characterization of DGZP polypeptides}

Which of the polypeptides from the DGZP fraction was responsible for the formation of these antibodies with an inhibitory effect on gamete interaction? By using a combination of preparative electrophoresis and electroelution, the deglycosylated polypeptides from the DGZP fraction have been purified to homogeneity on one-dimensional SDS/PAGE (Fig. 8). Polyclonal antibodies have been raised to each of the 4 polypeptides of higher molecular mass, DG-66, DG-52, DG-36 and DG-32 (Henderson et al., 1987b). The effects of these antisera on human gamete interaction are listed in Table 2. Although all the antisera inhibited human sperm binding to the human ZP to a 


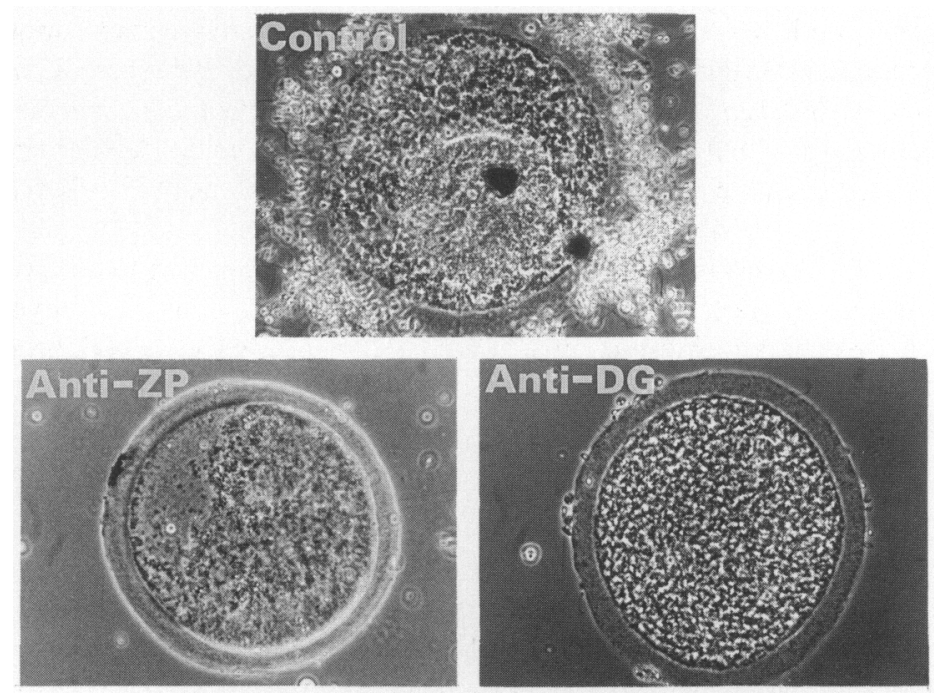

Fig. 7. Inhibition of human sperm binding to the human zona pellucida by antibodies raised to the intact and deglycosylated pig zona pellucida. Unfertilized human ova were incubated in antisera against the intact and deglycosylated pig zona pellucida before being exposed to capacitated human spermatozoa, according to Henderson et al. (1987a, b). Control antiserum was non-immune rabbit serum.

Table 2. Effects of antisera to components of the pig zona pellucida on human gamete interaction

\begin{tabular}{|c|c|c|c|c|c|c|c|c|}
\hline & \multicolumn{8}{|c|}{ Antiserum } \\
\hline & - ve & ZP & DGZP & $\begin{array}{c}M_{\mathrm{r}} \\
32000\end{array}$ & $\begin{array}{c}M_{\mathrm{r}} \\
36000\end{array}$ & $\begin{array}{c}M_{\mathrm{r}} \\
32 / 36000\end{array}$ & $\begin{array}{c}M_{\mathrm{r}} \\
52000\end{array}$ & $\begin{array}{c}M_{\mathrm{r}} \\
66000\end{array}$ \\
\hline$\%$ spermatozoa & 100 & 0.25 & $1 \cdot 3$ & $5 \cdot 3$ & $22 \cdot 4$ & $9 \cdot 2$ & $61 \cdot 5$ & $70 \cdot 3$ \\
\hline $\begin{array}{l}\text { bound } / 100 \mu \mathrm{m}^{2} \\
( \pm \text { s.e.m. })\end{array}$ & & $( \pm 0 \cdot 14)$ & $( \pm 0.06)$ & $( \pm 1 \cdot 2)$ & $( \pm 5 \cdot 8)$ & $( \pm 3 \cdot 5)$ & $( \pm 21 \cdot 6)$ & $( \pm 27 \cdot 8)$ \\
\hline No. of exps & 6 & 4 & 6 & 5 & 4 & 3 & 2 & 4 \\
\hline
\end{tabular}

certain degree, the only antiserum which approached the level of inhibition exhibited by the antisera against the ZP and DGZP fractions was that raised against the polypeptide of $M_{\mathrm{r}} 32000$, and this inhibited sperm-egg binding by almost $95 \%$.

By using indirect immunofluorescence techniques, the location of the antibody-binding sites can be determined. With antibodies to the ZP and DGZP fractions, and DG-32 (Fig. 9), the binding was localized to the outer surface of the zona pellucida and so the surface architecture of this structure can clearly be seen. Under dark-field illumination, the presence of a well-defined immunoprecipitate can be seen. In contrast, the remaining antisera (anti-DG-52 is used as an example in Fig. 7) failed to form an immunoprecipitate, and their binding to the zona pellucida was more generalized and diffuse throughout the structure. These results underline the importance of immunoprecipitate formation by the antisera in preventing sperm binding to the human zona pellucida.

As a consequence of these studies our major research efforts are now concentrating on the biochemical analysis of the component of $M_{\mathrm{r}} 32000$ from the pig zona pellucida as the basis for the 


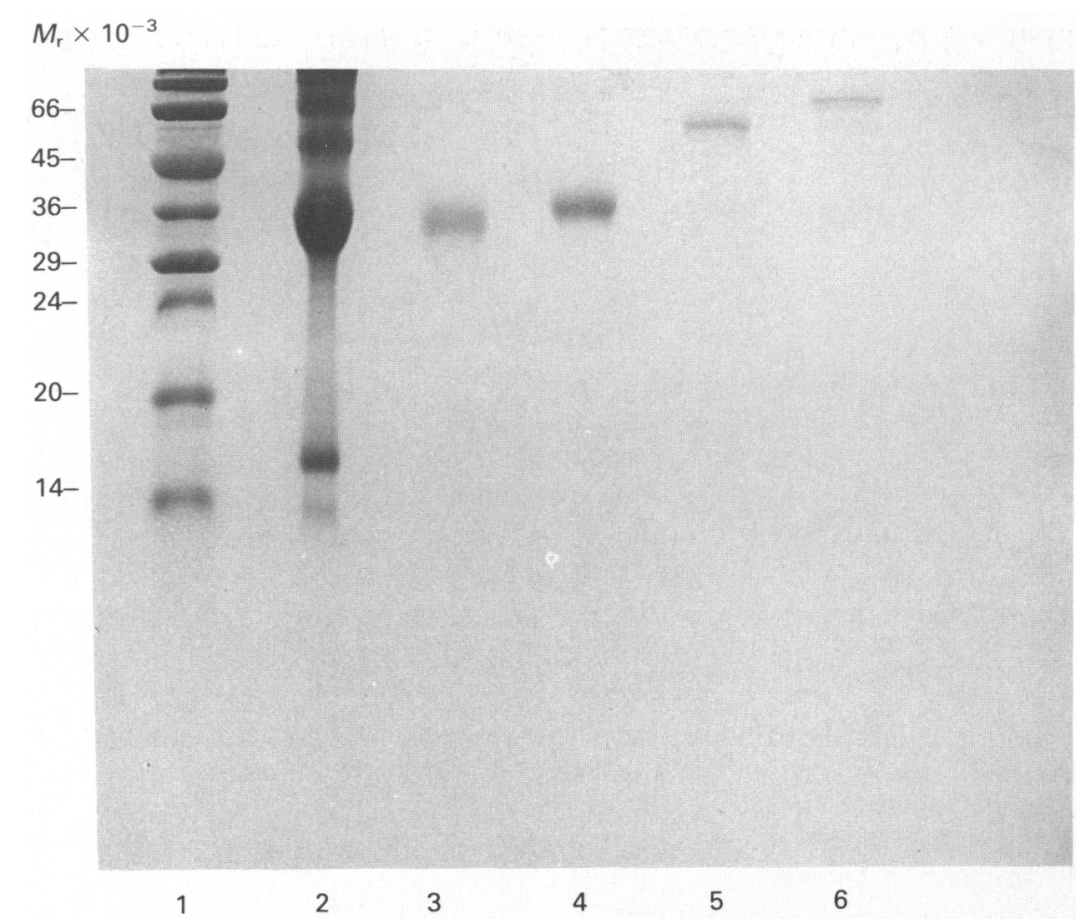

Fig. 8. One-dimensional electrophoresis of polypeptides isolated from the deglycosylated fraction of pig zonae pellucidae. One-dimensional sodium dodecylsulphate/polyacrylamide gel electrophoresis was carried out according to the method of Laemmli (1970). Samples of the polypeptides purified from the DGZP fraction (Henderson et al., 1987b) were prepared for electrophoresis by dissolution in a reduced sample buffer and run on a $10 \%$ acrylamide gel covering the molecular mass range approximately 10000-75000. Polypeptides were visualized by staining with Coomassie blue-R.

development of a contraceptive vaccine. This work has already begun with analysis of the amino acid composition and N-terminal sequence of DG-32 (unpublished data). Furthermore, we have undertaken the production of monoclonal antibodies to DG-32, and initial results indicate that some of these will bind to the outer surface of the human zona pellucida. As yet, however, we have failed to generate a monoclonal antibody with contraceptive effect; this is in accord with other published reports (Isojima et al., 1984, 1986; Koyama et al., 1985). However, we are persevering with the production of monoclonal antibodies, as the possession of such antibodies will be extremely important in defining the epitopes with contraceptive potential from the pig zona pellucida.

\section{The future...}

We have devised two parallel strategies for the future research in this programme (Table 3). One involves peptide chemistry, the other the use of recombinant DNA technology; both approaches utilize existing technology and both have the same goal-the elucidation of the primary amino acid sequence of DG-32, which will allow us to make full use of a new technique called epitope mapping (Geysen, 1985; Geysen et al., 1984, 1985). This powerful analytical technique will permit definition of the location of epitopes, with contraceptive potential, from DG-32 to a resolution of a single amino acid, and identify those amino acids within the epitope(s) which are essential for its biological effect. The strength of this method, with the production of a vaccine against the foot-and-mouth disease virus, has been demonstrated (Meloen \& Barteling, 1986). 

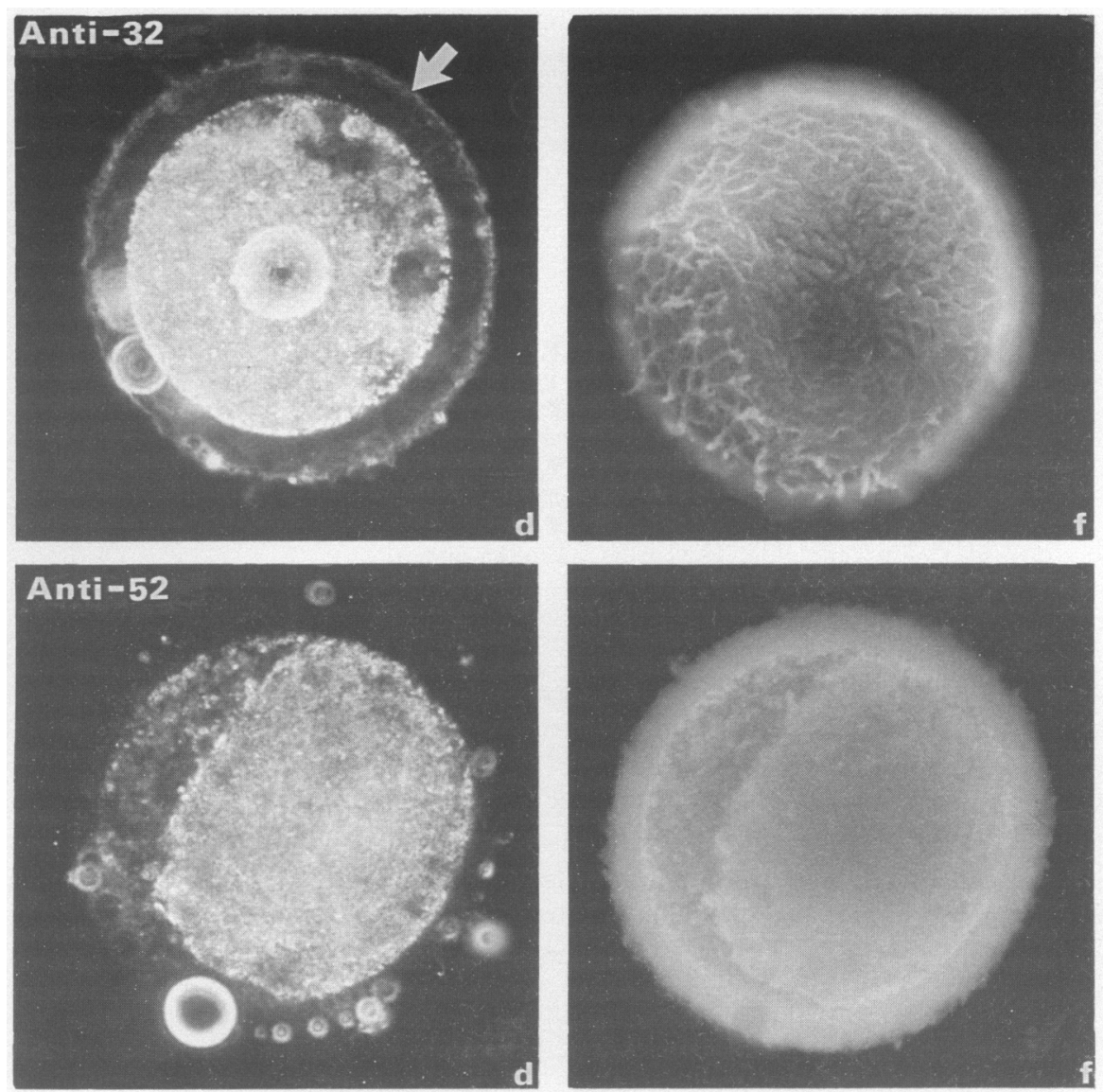

Fig. 9. Visualization of antibody binding to the human zona pellucida by indirect immunofluorescence. Salt-stored human ova were incubated with antisera raised against two polypeptides from the deglycosylated fraction of the pig zona pellucida (DGZP), DG-32 or DG-52 (Henderson et al. , 1987b) for $1 \mathrm{~h}$ at $37^{\circ} \mathrm{C}$. These eggs were then further incubated in a second, fluoresceinlabelled, antibody for $30 \mathrm{~min}$ at $37^{\circ} \mathrm{C}$. Visualization of antibody binding was achieved using a fluorescence microscope ( $f=$ fluorescence, $d=$ dark-field conditions). The presence of an immunoprecipitate on the outer surface of the zona pellucida, with antibodies to DG-32, is indicated by the white arrow. No immunoprecipitate is found with anti-DG-52 antiserum.

Once the contraceptive epitopes on DG-32 have been defined, a start can be made on the engineering of a vaccine. Here too, the application of new technology can play a part with the possibility of using genetic engineering techniques to insert the DNA coding for the appropriate zona antigens into Vaccinia virus; the altered virus could then be used as a vehicle for the administration of a contraceptive vaccine. Several foreign genes have already been cloned into Vaccinia (Keus, 1986), including hepatitis B virus surface antigen (Moss et al., 1984), herpes simplex virus glycoprotein D (Cremer et al., 1985), rabies virus glycoprotein $G$ (Kieny et al., 1984), influenza virus haemagglutinin (Panicali et al., 1983) and malaria sporozoite antigen (Smith et al., 1984). All of these recombinants have been successfully tested in laboratory animals, while the hepatitis recombinant has also been tested in chimpanzees, with the animals rendered resistant to the hepatitis B virus. Alternatively, the possibility exists of using biodegradable depot formulations for the delivery of a contraceptive vaccine (Langer, 1981; Hutchinson \& Furr, 1987). 
Table 3. Future strategy for the development of a contraceptive vaccine

\section{Peptide chemistry}

Chemical/enzymic fragmentation of DG-32

Identification of cross-reactive fragments by ELISA/immunoblotting

Isolation/sequencing of cross-reactive fragments
Recombinant DNA

Isolate/sequence $\mathrm{N}$-terminus

Synthesize nucleotide probes

Prepare cDNA library

Identify recombinant

Isolate/sequence insert DNA

Nick translation

Screen human genomic library

Isolate/sequence insert DNA

\author{
Epitope mapping \\ $\nabla$ \\ Peptide synthesis \\ Vaccine engineering \\ $\nabla$ \\ Active immunization studies
}

Vaccines based on synthetic peptides have been formulated against a wide range of bacterial, viral and parasitic infections, including diphtheria (Audibert et al., 1982), cholera (Jacob et al., 1984), hepatitis B (Gerin et al., 1983), influenza (Wilson et al., 1984), poliomyelitis (Emini et al., 1983), malaria (Patarroyo et al., 1987) and HIV (Kennedy et al., 1986). There is no reason to doubt, then, the feasibility of a contraceptive vaccine based on synthetic zona pellucida antigens.

The production of a safe, reliable and effective contraceptive vaccine is still some time away; however, research over the past 15 years has not only established the principle of basing a vaccine on zona-specific antigens, but also put the biochemical basis for the development of such a vaccine within our grasp.

C.J.H. is the holder of an MRC/Celltech Training Fellowship. We thank Professor A. A. Templeton, Department of Obstetrics and Gynaecology, University of Aberdeen, Dr V. J. Bolton, IVF Unit, King's College, London, Dr P. Braude, Department of Obstetrics and Gynaecology, University of Cambridge, for assistance and co-operation; and Hall's Ltd, of Broxburn, West Lothian, U.K. for the supply of pig ovaries.

\section{References}

Ahuja, K.K. \& Tzartos, S.J. (1981) Investigation of sperm receptors in the hamster zona pellucida using univalent (Fab) antibodies to hamster ovary. $J$. Reprod. Fert. 61, 257-264.

Aitken, R.J. \& Richardson, D.W. (1980) Immunization against zona pellucida antigens. In Immunological Aspects of Reproduction and Fertility Control, pp. 173-201. Ed. J. P. Hearn. MTP Press, Lancaster.

Aitken, R.J. \& Richardson, D.W. (1981a) Measurement of sperm-binding capacity of mouse zona pellucida and use in estimation of antibody titres. J. Reprod. Fert. 63, 295-307.

Aitken, R.J. \& Richardson, D.W. (1981b) Mechanism of sperm-binding inhibition by anti-zona antisera. Gamete Res. 4, 41-47.

Aitken, R.J. \& Richardson, D.W. (1981c) Active immunization of rats with cumulus-free ova: induction of infertility and antibody titres. J. exp. Zool. 216, 149-158.
Aitken, R.J., Rudak, E-A., Richardson, D.W., Dor, J., Djahanbahkch, O. \& Templeton, A.A. (1981) Influence of anti-zona and anti-sperm antibodies on sperm-egg interactions. J. Reprod. Fert. 62, 597-606.

Aitken, R.J., Holmes, E., Richardson, D.W. \& Hulme, M.J. (1982) Properties of intact and univalent (Fab) antibodies raised against isolated, solubilized mouse zonae. J. Reprod. Fert. 66, 327-334.

Aitken, R.J., Richardson, D.W. \& Hulme, M.J. (1984) Immunological interference with the properties of the zona pellucida. In Immunological Aspects of Reproduction in Mammals pp. 305-325. Ed. D. B. Crighton, Butterworths, London.

Audibert, F., Jolivet, M., Chedid, L., Arnon, R. \& Sela, M. (1982) Successful immunization with a totally synthetic diphtheria vaccine. Proc.natn. Acad.Sci.U.S.A. 79, 5042-5046.

Bamezai, A.K., Suman, A. Das, C. \& Talwar, G.P. (1986) Effect of immunization against pig zona pellucida 
(PZP) on steroid hormone profiles and fertility in primates. J. Rep. Immunol. 9, Suppl., p. 85, Abstr.

Barros, C. \& Yanagimachi, R. (1972) Polyspermypreventing mechanisms in the Golden Hamster egg. J. exp. Zool. 180, 251-266.

Bedford, J.M. (1977) Sperm/egg interaction: the specificity of human spermatozoa. Anat. Rec. 188, 477-488.

Bedford, J.M. \& Cross, N.L. (1978) Normal penetration of rabbit spermatozoa through a trypsin- and acrosinresistant zona pellucida. J. Reprod. Fert. 54, 385-392.

Biggers, J.D., Whitten, W.K. \& Whittingham, D.G. (1971) The culture of mouse embryos in vitro. In Methods in Mammalian Embryology, pp. 86-116. Ed. J. C. Daniel, Jr. Freeman, San Fransciso.

Cremer, K.J., Mackett, M., Wohlenberg, C., Notkins, A.L. \& Moss, B. (1985) Vaccinia virus recombinant expressing herpes simplex virus type 1 glycoprotein D prevents latent herpes in mice. Science, N.Y. 228, 737-740.

Dor, J., Rudak, E-A. \& Aitken, R.J. (1981) Anti-sperm antibodies: their effect on the process of fertilization studied in vitro. Fert. Steril. 35, 535-541.

Dudkiewicz, A.B., Noske, I.G. \& Shivers, C.A. (1975) Inhibition of implantation in the Golden Hamster by zona-precipitating antibody. Fert. Steril. 28, 686-691.

Dunbar, B.S. \& Raynor, B.D. (1980) Characterization of porcine zona pellucida antigens. Biol. Reprod. 22, 941-954.

Dunbar, B.S., Wardrip, N.J. \& Hedrick, J.L. (1980) Isolation, physicochemical properties and macromolecular composition of zonae pellucidae from porcine oocytes. Biochemistry, N.Y. 2, 356-365.

Dunbar, B.S., Liu, C. \& Sammons, D.W. (1981) Identification of the three major proteins of porcine and rabbit zonae pellucidae by high resolution twodimensional gel electrophoresis: comparison with serum, follicular fluid and ovarian cell proteins. Biol. Reprod. 24, $1111-1124$.

East, I., Mattison, D.R. \& Dean, J. (1984) Monoclonal antibodies to the major protein of the murine zona pellucida: effects on fertilization and early development. Devl. Biol. 104, 49-56.

East, I., Gulyas, B.J. \& Dean, J. (1985) Monoclonal antibodies to the murine zona pellucida protein with sperm receptor activity: effects on fertilization and early development. Devl Biol. 109, 268-273.

Emini, E.A., Jameson, B.A. \& Wimmer, E. (1983) Priming for and induction of anti-poliovirus neutralizing antibodies by synthetic peptides. Nature, Lond. 304, 699-703.

Florman, H.M. \& Wassarman, P.M. (1985) O-linked oligosaccharides of mouse egg ZP3 account for its sperm receptor activity. Cell 41, 313-324.

Gerin, J.L., Alexander, H., Shih, J.W., Purcell, R.H., Dapolito, T., Engle, R., Green, N., Sutcliffe, J.G., Shinnick, T.M. \& Lerner, R.A. (1983) Chemically synthesized peptides of Hepatitis B surface antigen duplicate the $d / y$ specificities and induce subtypespecific antibodies in chimpanzees. Proc. natn. Acad. Sci. U.S.A. 80, 2365-2369.

Geysen, H.M. (1985) Antigen-antibody interactions at the molecular level: adventures in peptide synthesis. Immunol. Today 6, 364-369.

Geysen, H.M., Moloen, R.H. \& Barteling, S.J. (1984) Use of peptide synthesis to probe viral antigens for epitopes to a resolution of a single amino acid. Proc. natn. Acad. Sci. U.S.A. 81, 3998-4002.

Geysen, H.M., Barteling, S.J. \& Moloen, R.H. (1985) Small peptides induce antibodies with a sequence and structural requirement for binding antigen comparable to antibodies raised against the native protein. Proc. natn. Acad. Sci. U.S.A. 82, 178-182.

Gulyas, B.J., Gwatkin, R.B.L. \& Yuan, L.C. (1983) Active immunization of Cynomolgus monkeys (Macaca fascicularis) with porcine zonae pellucidae. Gamete Res. 4, 299-307.

Gwatkin, R.B.L. \& Williams, D.T. (1976) Receptor activity of the solubilized hamster and mouse zona pellucida before and after the zona reaction. $J$. Reprod. Fert. 49, 55-59.

Gwatkin, R.B.L., Williams, D.T. \& Carlo, D.J. (1977) Immunization of mice with heat-solubilised hamster zonae: production of anti-zona antibody and inhibition of fertility. Fert. Steril. 28, 871-877.

Gwatkin, R.B.L., Andersen, O.F. \& Williams, D.T. (1980) Immunization of female rabbits with heat-solubilized bovine zonae: production of anti-zona antibody and inhibition of fertility. Gamete Res. 1, 1926.

Hanada, A. \& Chang, M.C. (1972) Penetration of zonafree eggs by spermatozoa of different species. Biol. Reprod. 6, 300-309.

Hartmann, J.F. \& Gwatkin, R.B.L. (1971) Alteration of sites on the mammalian sperm surface following capacitation. Nature, Lond. 234, 479-481.

Hartmann, J.F., Gwatkin, R.B.L. \& Hutchinson, C.F. (1972) Early contact interactions between mammalian gametes in vitro; evidence that the vitellus influences adherence between sperm and zona pellucida. Proc. natn. Acad. Sci. U.S.A. 69, 2767-2769.

Hasegawa, A., Ikeda, Y., Li, Y., Shigeta, M., Koyama, K. \& Isojima, S. (1985) Blocking effect of antiserum raised to purify porcine zona pellucida antigen on sperm binding to oocytes in human. Acta obstet. gynaec.jap. 37, 2639, Abstr. 17.

Hearn, J.P., Lunn, S.F., Burden, F.J. \& Pilcher, M.M. (1975) Management of marmosets for medical research. Lab. Anim. 9, 125-134.

Hedrick, J.L. \& Wardrip, N.J. (1981) Microheterogeneity of zona glycoproteins is due to carbohydrate. J. Cell Biol. 91, 77a, Abstr.

Hedrick, J.L. \& Wardrip, N.J. (1986) Isolation of zonae pellucidae and purification of its glycoprotein families from pig oocytes. Analyt. Biochem. 157, 63-70.

Hedrick, J.L., Wardrip, N.J. \& Urch, U.A. (1985) The chemistry of the zona pellucida and its function as a substrate for acrosin. Dev. Growth Diff. 27, p. 175, Abstr.

Henderson, C.J., Hulme, M.J. \& Aitken, R.J. (1987a) Analysis of the biological properties of antibodies raised against intact and deglycosylated porcine zonae pellucidae. Gamete Res. 16, 323-341.

Henderson, C.J., Braude, P. \& Aitken, R.J. (1987b) Polyclonal antibodies to a $32 \mathrm{kDa}$ deglycosylated polypeptide from the porcine zona pellucida will prevent human gamete interaction in vitro. Gamete Res. 18, 251-265.

Hulme, M.J., Aitken, R.J. \& Richardson, D.W. (1982) Use of a radioimmunoassay technique to measure titre of anti-cow zona antibodies in marmosets. Gamete Res. 5, 271-281. 
Hutchinson, F.G. \& Furr, B.J.A. (1987) Biodegradable carriers for the sustained release of polypeptides. Trends in Biotechnol. 5, 102-106.

Isojima, S., Koyama, K., Hasagewa, A., Tsunoda, Y. \& Hanada, A. (1984) Monoclonal antibodies to porcine zona pellucida antigens and their inhibitory effects on fertilization. J. Reprod. Immunol. 6, 77-87.

Isojima, S., Koyama, K., Takada, Y., Shigeta, M., Tsuji, Y. \& Hasegawa, A. (1986) The development of a contraceptive vaccine by purification of antigens from gametes. Am. J. Reprod. Microbiol. 10, 90-92.

Jacob, C.O., Pines, M. \& Arnon, R. (1984) Neutralization of heat-labile toxin of $\mathrm{E}$. Coli by antibodies to synthetic peptides derived from the $\beta$ subunit of cholera toxin. EMBO J. 3, 2889-2893.

Jivek, F. \& Pavlok, A. (1975) Antibodies against mouse ovaries and their effect on fertilization in vitro and in vivo in the mouse. J. Reprod. Fert. 42, 377-380.

Karp, D.R., Atkinson, J.P. \& Shreffler, D.C. (1982) Genetic variation in glycosylation of fourth component of murine complement. J. biol. Chem. 257, 7330-7335.

Kennedy, R.C., Henkel, R.D., Paoletti, D., Allen, J.S., Lee, T.H., Essex, M. \& Dreesman, G.R. (1986) Antiserum to a synthetic peptide recognizes the HTLV-III envelope glycoprotein. Science, N.Y. 231, 1556-1559.

Keus, J.A.R. (1986) An accidental human trial of recombinant vaccinia virus: a step towards acceptance of live recombinant vaccines? Trends in Biotechnol. 4, 105-106.

Kieny, M.P., Lathe, R., Drillien, R., Spehner, D., Skory, S., Schmitt, D., Wiktor, T., Koprowski, H. \& Lecoq, J.P. (1984) Expression of rabies virus glycoprotein from a recombinant vaccinia virus. Nature, Lond. 312, 163-166.

Koyama, K., Hasegawa, A., Tsuji, Y. \& Isojima, S. (1985) Production and characterization of monoclonal antibodies to cross-reactive antigens of human and porcine zonae pellucidae. J. Reprod. Immunol. 7, 187-198.

Laemmli, U.K. (1970) Cleavage of structural proteins during the assembly of the head of bacteriophage T4. Nature, Lond. 227, 680-685.

Langer, R. (1981) Polymers for the sustained release of macromolecules: their use in a single-step method of immunization. Methods Enzymol. 73, 57-75.

Mahi-Brown, C.A., Huang, T.T.F., Jr \& Yanagimachi, R. (1982) Infertility in bitches induced by active immunization with porcine zonae pellucidae. $J$, exp. Zool. 222, 89-95.

Mahi-Brown, C.A., Yanagimachi, R., Hoffman, J.C. \& Huang, T.T.F., Jr (1985) Fertility control in the bitch by active immunization with porcine zonae pellucidae: use of different adjuvants and patterns of estradiol and progesterone levels in estrous cycles. Biol. Reprod. 32, $761-772$.

Meloen, R.H. \& Barteling, S.J. (1986) Epitope mapping of the outer structural protein VPl of three different serotypes of foot-and-mouth disease virus. Virology 149, 55-63.

Mori, T., Kamada, M., Yamano, S., Kinoshita, T., Kano, K. \& Mori, T. (1985) Production of monoclonal antibodies to porcine zona pellucida and their inhibition of sperm penetration through human zona pellucida in vitro. J. Reprod. Immunol. 8, 1-11.
Moss, B., Smith, G.L., Gerin, J.L. \& Purcell, R.H. (1984) Live recombinant vaccinia virus protects chimpanzees against hepatitis B. Nature, Lond. 311, 67-69.

Noda, Y., Mori, T., Kohda, H. \& Nishimuri, T. (1981) A new method for the preparation of pure zonae pellucidae in large quantities from porcine ovaries. $J$. Reprod. Immunol. 3, 147-156.

Noda, Y., Kohda, H., Takai, I., Hayashi, S., Shimada, H., Mori, T. \& Tojo, S. (1983) Characterization of glycoproteins isolated from the porcine zona pellucida. $J$. Reprod. Immunol. 5, 161-172.

O'Farrell, P.H. (1975) High resolution two-dimensional electrophoresis of proteins. J. biol. Chem. 250, 4007-4021.

Oikawa, T. \& Yanagimachi, R. (1975) Block of hamster fertilization by anti-ovary antibody. J. Reprod. Fert. 45, $487-494$.

Oikawa, T., Nicolson, G.L. \& Yanagimachi, R. (1975a) Trypsin-mediated modification of the zona pellucida glycopeptide structure of hamster eggs. J. Reprod. Fert. 43, 133-136.

Oikawa, T., Yanagimachi, R. \& Nicolson, G.L. (1975b) Wheat-germ agglutinin blocks mammalian fertilization. Nature, Lond. 241, 487-494.

Palm, V.S., Sacco, A.G., Syner, F. \& Subramanian, M.G. (1979) Tissue specificity of porcine zona pellucida antigens as tested by radioimmunoassay. Biol. Reprod. 21, 709-713.

Panicali, D., Davies, S.W., Weinberg, R.L. \& Paoletti, E. (1983) Construction of live vaccines by using genetically engineered poxviruses: biological activity of recombinant vaccinia virus expressing influenza virus haemagglutinin. Proc. natn. Acad. Sci. U.S.A. 80, 5364-5368.

Patarroyo, M.E., Romero, P., Torres, M.L., Clavijo, P., Moreno, A., Martinez, A., Rodriguez, R., Guzman, F. \& Cabezas, E. (1987) Induction of active immunity against experimental infection with malaria using synthetic peptides. Nature, Lond. 328, 629-632.

Population Statistics Division, Office of Population Censuses and Surveys (1987) Global population: projections and trends. Population Trends 47, 12-15.

Sacco, A.G. (1977) Antigenic cross-reactivity between human and pig zona pellucida. Biol. Reprod. 16, $164-173$.

Sacco, A.G. (1979) Inhibition of fertility in mice by passive immunization with antibodies to isolated zonae pellucidae. J. Reprod. Fert. 56, 533-537.

Sacco, A.G. \& Shivers, C.A. (1973) Localization of tissue-specific antigens in the rabbit ovary, oviduct and uterus by the fluorescent antibody technique. $J$. Reprod. Fert. 32, 415-420.

Sacco, A.G., Yurewicz, E.C., Subramanian, M.G. \& DeMayo, F.J. (1981) Zona pellucida composition: species cross-reactivity and contraceptive potential of antiserum to a purified pig zona antigen (PPZA). Biol. Reprod. 25, 997-1008.

Sacco, A.G., Yurewicz, E.C. \& Zhang, S. (1983a) Immunoelectrophoretic analysis of porcine zonae pellucidae. J. Reprod. Fert. 68, 21-31.

Sacco, A.G., Subramanian, M.G., Yurewicz, E.C., DeMayo, F.J. \& Dukelow, W.R. (1983b) Heteroimmunization of squirrel monkeys (Saimiri sciureus) with a purified porine zona antigen (PPZA): immune 
response and biologic activity of antiserum. Fert. Steril. 39, 350-358.

Sacco, A.G., Subramanian, M.G. \& Yurewicz, E.C. (1984) Association of sperm receptor activity with a purified pig zona antigen (PPZA). J. Reprod. Immunol. 6, 89-103.

Sacco, A.G., Subramanian, M.G. \& Yurewicz, E.C., Pierce, D.L. \& Dukelow, W.R. (1986a) Antigenic profile and impact of immunization with zona pellucida antigens in primates. In Immunological Approaches to Contraception and Promotion of Fertility, pp. 277-290. Ed G.P. Talwar. Plenum Publishing Corporation.

Sacco, A.G., Yurewicz, E.C. \& Subramanian, M.G. (1986b) Carbohydrate influences the immunogenic and antigenic characteristics of the ZP3 macromolecule $\left(M_{\mathrm{r}} 55000\right)$ of pig zonae pellucidae. J. Reprod. Fert. 76, 575-586.

Sacco, A.G., Pierce, D.L., Subramanian, M.G., Yurewicz, E.C. \& Dukelow, W.R. (1987) Ovaries remain functional in squirrel monkeys (Saimiri sciureus) immunized with porcine zona pellucida 55000 macromolecule. Biol. Reprod. 36, 481-490.

Shivers, C.A. (1974) Immunological interference with fertilization. Acta endocr., Copenh., Suppl. 194, 223-244.

Shivers, C.A., Dudkiewicz, A.B., Franklin, L.E. \& Fussel, E.N. (1972) Inhibition of sperm-egg interaction by specific antibody. Science, N.Y. 178, 1211-1213.

Skinner, S.M. \& Dunbar, B.S. (1984) Comparison of immunization using zona pellucida (ZP) protein or total ZP protein on ovarian follicular development. Biol. Reprod. 30, Suppl. 1, p. 73, Abstr. 85.

Skinner, S.M., Mills, T., Kirchick, H.J. \& Dunbar, B.S. (1984) Immunization with zona pellucida proteins results in an abnormal ovarian follicular differentiation and inhibition of gonadotrophin-induced steroid secretion. Endocrinology 115, 2418-2432.

Smith, G., Godson, G.N., Nussenzweig, V., Nussenzweig, P.S., Barnwell, J. \& Moss, B. (1984) Plasmodium knowlesli sporozoite antigen: expression by infectious recombinant vaccinia virus. Science, N.Y. 224, $397-399$.

Timmons, T.M., Maresh, G.A., Bundman, D.S. \& Dunbar, B.S. (1987) Use of specific monoclonal and polyclonal antibodies to define distinct antigens of the porcine zona pellucida. Biol. Reprod. 36, 1275-1287.

Trounson, A.O., Shivers, C.A., McMaster, R. \& Lopata, A. (1980) Inhibition of sperm binding and fertilization of human ova by antibody to porcine zona pellucida and human sera. Archs Androl. 4, 29-35.

Tșunoda, Y. (1977) Inhibitory effect of anti-mouse egg serum on fertilization in vitro and in vivo in the mouse. J. Reprod. Fert. 50, 353-355.
Tsunoda, Y. \& Chang, M.C. (1976a) Reproduction in rats and mice isoimmunized with homogenates of ovary or testis with epididymis, or sperm suspensions. $J$. Reprod. Fert. 46, 379-382.

Tsunoda, Y. \& Chang, M.C. (1976b) Effect of anti-rat ovary antiserum on the fertilisation of mouse and hamster eggs in vivo and in vitro. Biol. Reprod. 14, $354-361$.

Tsunoda, Y. \& Chang, M.C. (1977) Further studies of antisera on the fertilization of mouse, rat and hamster eggs in vivo and in vitro. Int. J. Fert. 22, 129-139.

Tsunoda, Y. \& Chang, M.C. (1978) Effect of antisera against eggs and zonae pellucidae on fertilization and development of mouse eggs in vivo and in culture. $J$. Reprod. Fert. 54, 233-237.

Tsunoda, Y. \& Sugie, T. (1977) Inhibition of fertilization in mice by anti-zona pellucidae antiserum. Jap. $J$. Zootech. Sci. 48, 784-790.

Tsunoda, Y. \& Whittingham, D.G. (1982) Lack of effect of zona antibodies on development of mouse embryos in vivo and in vitro. J. Reprod. Fert. 66, 885-889.

Tsunoda, Y., Sugie, T., Mori, J., Isojima, S. \& Koyama, K. (1981) Effect of purified zona antibody on fertilization in the mouse. J. exp. Zool. 271, 103-108.

Wardrip, N.J., Goldhawk, D.E. \& Hendrick, J.L. (1986) The $55 \mathrm{k}$ glycoprotein family of porcine zona pellucida contains two chemically and immunologically distinct components. Dev. Growth Diff. 29, p. 102, Abstr. 149.

Wilson, I.A., Niman, H.L., Houghton, R.A., Cherenson, A.R., Connolly, M.L. \& Lerner, R.A. (1984) The structure of an antigenic determinant in a protein. Cell 37, 767-778.

Wood, D.M., Liu, C. \& Dunbar, B.S. (1981) Effect of alloimmunization and heteroimmunization with zonae pellucidae on fertility in rabbits. Biol. Reprod. 25, $439-450$.

Yanagimachi, R., Lopato, A., Adom, C. Bronson, R.A., Mahi, C.A. \& Nicolson, G.L. (1979) Retention of biologic characteristics of zona pellucida in highly concentrated salt solution: the use of salt-stored eggs for assessing the fertilizing capacity of spermatozoa. Fert. Steril. 31, 562-574.

Yurewicz, E.C., Sacco, A.G. \& Subramanian, M.G. (1983) Isolation and preliminary characterization of a purified pig zona antigen (PPZA) from porcine oocytes. Biol. Reprod. 29, 511-523.

Yurewicz, E.C., Sacco, A.G. \& Subramanian, M.G. (1987) Structural characterization of the $\mathrm{Mr}=55000$ antigen (ZP3) of porcine oocyte zona pellucida. $J$. biol. Chem. 262, 564-571.

Received 14 September 1987 